\title{
Böbrek Hastalıklarında Beslenme Durumunun Saptanması
}

\author{
Nutritional Assessment in Kidney Diseases
}

\section{Perim F. Türker ${ }^{1}$}

Geliş tarihi/Received: 20.03.2018 • Kabul tarihi/Accepted: 05.12.2018

\section{ÖZET}

Kronik böbrek hastalıkları insidansı ve prevalansı tüm dünyada artmaktadır. Türk Nefroloji Derneği verilerine göre son 10 yılda ülkemizde son dönem böbrek yetmezliği (SDBY) insidansında iki kat, prevalansında beş kat artış gözlenmiştir. Kronik böbrek yetmezliğine eşlik eden üremik sendrom iştah kaybıyla, azalmış oral besin alımıyla sonuçlanan gastrointestinal yan etkilerle, metabolik asidoz, endokrin etmenler, üremik toksisite, protein katabolizmasının başlamasıyla ilişkilidir. Malnütrisyon SDBY olan hastalarda önemli bir sorundur. SDBY tanısı konmuş hastalarda protein nereji malnütrisyonunun (PEM) bulunma oranı hemodiyaliz (HD) hastalarında \%18-75, sürekli ayaktan periton diyaliz (SAPD) hastalarında \%1050 arasındadır. Protein enerji malnütrisyon varlığı SDBY'de artmış mortalite ve morbidite ile ilişkilidir. Malnütrisyon sık görüldüğü için, beslenme durumunun periyodik olarak değerlendirilmesi, erken tanı ve uygun tedavide böbrek hastalarının rutin bakımının bir parçasıdır. Bu derleme makalede, böbrek hastalıklarında beslenme durumu saptama durumlarına odaklanilacaktır.

Anahtar kelimeler: Böbrek hastalıkları, malnütrisyon, beslenme durumu

\begin{abstract}
The incidence and prevalence of chronic kidney disases is increasing globally. According to the data of the Turkish Nephrology Society, end stage renal disease (ESRD) incidence was increased two times and prevalence was increased five times in the last 10 years in Turkey. Uremia decreases appetite and causes reduced food intake that is related with its negative effects on the gastrointestinal system function metabolic asidosis, endocrine factors, uremic toxicity, induction of protein catabolism, etc. Protein energy malnutrition(PEM) is an important problem in ESRD. PEM rates of the hemodialysis and peritoneal dialysis patients are 18-75\% and 10-50\%, respectively. Protein energy malnutrition in ESRD is strongly related with increased morbidity and mortality. As a result of the frequency of malnutrition, periodic assessment of nutritional status should be part of the routine care of kidney patients to permit early recognition and the institution of appropriate therapy. In this review article, we focus on nutritional assessment in chronic kidney disease.
\end{abstract}

Keywords: Kidney diseases, malnutrition, nutritional assessment

1. İletişim/Correspondence: Başkent Üniversitesi, Sağlık Bilimleri Fakültesi, Beslenme ve Diyetetik Bölümü, Ankara, Türkiye • E-posta: pfturker@baskent.edu.tr (ㄱ) https://orcid.org/0000-0002-4254-3711 


\section{GíRiş}

Kronik böbrek hastalıkları insidansı ve prevalansı tüm dünyada artmaktadır. Amerika Birleşik Devletleri Renal Data Sistemi (USRDS) 2013 yllı verilerine göre Türkiye'de son dönem böbrek yetmezliği (SDBY) insidansı nokta milyon nüfus başına 238, prevalansı ise 870 olarak saptanmıştır. Türk Nefroloji Derneği verilerine göre son 10 yılda ülkemizde SDBY insidansında iki kat, prevalansında beş kat artış gözlenmiştir (1,2). SDBY olan hastalarda azalmış yaşam kalitesi ve sağkalımın yanında yüksek morbidite ve mortalite oranları vardır (3). Ülkemizdeki hastaların ylllk mortalite oranları ise \%9.4 olarak bildirilmiştir (2). Kronik böbrek yetmezliğine eşlik eden üremik sendrom iştah kaybıyla, azalmış oral besin alımıyla sonuçlanan gastrointestinal yan etkilerle, metabolik asidoz, endokrin etmenler, üremik toksisite, protein katabolizmasının başlamasıyla ilişkilidir. SDBY'de sistemik komplikasyonlar nedeniyle mortaliteye yol açan nedenlerden biri kardiyovasküler hastalıklar olarak belirtilmiştir. Bunun dışında, protein enerji malnütrisyonu da özellikle diyaliz hastalarında mortalite ve morbidite için önemli bir risk etmenidir (3).

Böbrek işlevlerinin ilerleyici kaybı ile volüm yüklenmesi, hiperkalemi, metabolik asidoz, hiperfosfatemi, endokrin ve hormonal bozukluklar, hipertansiyon, hiperlipidemi, anemi, renal osteodistrofi, asidozis, ödem, beslenme bozuklukları olan malnütrisyon gibi komplikasyonlar gelişmeye başlar (4). $\mathrm{Bu}$ derleme makalede, böbrek hastalıklarında beslenme durumu saptama durumlarına odaklanılacaktır.

\section{Son Dönem Böbrek Yetmezliği ve Malnütrisyon}

Protein enerji malnütrisyonu (PEM) varlığı son dönem böbrek yetmezliği olan hastalarda sık saptanan bir bulgudur. SDBY tanısı konmuş hastalarda PEM'in bulunma oranı hastanın malnütrisyonunu belirlemek için kullanılan yöntemlerin seçimine göre değişmekle birlikte hemodiyaliz (HD) hastalarında \%18-75, sürekli ayaktan periton diyaliz (SAPD) hastalarında \%10-50 arasındadır. Protein enerji malnütrisyon varlığı SDBY'de artmış mortalite ve morbidite ile ilişkilidir $(5,6)$. Yapılan bir çalışmada diyaliz tedavisi gören hastalarda düşük serum albümin ve kan üre azot (BUN) düzeyi ile mortalite arasında bağlantı olduğu belirtilmiştir (7). Diyaliz hastalarında hipoalbümineminin primer nedeni malnütrisyondur (8). Diyalize giren hastalarda diyaliz öncesi serum albümin değerinin $3.4 \mathrm{~g} / \mathrm{dL}$, kreatinin değerinin $8 \mathrm{mg} /$ dL altında olması, ideal vücut ağırlığına göre \%10'dan fazla ağırlık kaybı, biyokimyasal parametrelerin malnütrisyonu göstermesi, diyet ile protein alımının günlük $0.8 \mathrm{~g} / \mathrm{kg}$ ve enerji alımının $25 \mathrm{kkal} / \mathrm{kg} / \mathrm{gün}$ altında oluşu malnütrisyonu tanımlayan bulgulardır. Malnütrisyon, ayrıca protein, enerji ve diğer besin ögelerinin alımı, kayıplar ve gereksinmeler arası dengesizlikler sonucu oluşan bir tablo olarak da tanımlanabilir (9).

Kronik böbrek yetmezliğinde pekçok nedenle malnütrisyon gelişebilmektedir. Hastaların malnütrisyon derecelerine göre yaşam kaliteleri de bozulmaktadır. Malnütrisyon tedavi edildiğinde hastaların yaşam kalitesi iyileştirilebilmektedir. SDBY olan hastalarda malnütrisyona neden olan ve beslenmeyi etkileyen birbiri ile ilişkili birçok etmen vardır (Tablo 1) $(10,11)$.

\section{Böbrek Hastalıklarında Beslenme Durumunun Değerlendirilmesi}

Malnütrisyon birçok etmenin değişik derecelerde katkıda bulunduğu bir bulgu olduğu için son dönem böbrek yetmezliği olan SAPD veya HD’e giren hastalarda protein enerji malnütrisyonunu en hatasız şekilde hangi yöntemin gösterebileceğini bulmak için araştırmalar yapılmış, bunların sonucunda basit ya da karmaşık birçok yöntem geliştirilmiştir. Ancak bu testlerden hiçbiri günümüzde PEM’i hatasız olarak göstermek için tek başına yeterli değildir ve bu konuda altın standart bir test yoktur. Bu nedenle SDBY olan hastaların beslenme durumlarını belirlemek için bu yöntemlerin birlikte kullanılmalarıyla daha hassas bir sonuç elde edileceği belirtilmektedir $(5,12,13)$. 
Tablo 1. Renal hastalıklarda malnütrisyonun nedenleri $(10,11)$

Besin alımında azalma

1.Diyette aşırı kısıtlama, anoreksiya

2.Gastrik boşalmanın gecikmesi ve diyare

3.Eşlik eden hastalıklar ve hospitalizasyon

4.Dispepsiye yol açan ilaçlar (fosfat bağlayıcılar ve demir preperatlarl)

5.Yetersiz hemodiyaliz, hemodiyalizle ilişkili bulantı-kusma

6.Peritona dekstroz verilmesi ile oluşan besin alımında azalma

7.Psikososyal etmenler, leptin düzeylerinin artması

8.Üremiye bağlı tat alma duyusunda azalma

9.Vitamin kayıpları, ilaç yan etkileri

\section{Protein katabolizmasının artması}

1. Metabolik asidoz

2. Hemodiyalize bağlı olarak katabolizmanın artması

3.Büyüme hormonu, insülin benzeri büyüme faktörü gibi endokrin işlev bozuklukları

4.Paratiroid, kortizol ve glukagon hormonlarının katabolik etkisi

Kayıpların artması

1.Gastrointestinal kan kaybı, intradiyalitik azot kayıpları

2.Hemodiyaliz ve periton diyalizinde aminoasit ve diğer metabolitlerin kaybı

3.Hemodiyaliz sırasında kronik kan kaybı

4.Yetersiz diyaliz, diyalizatla peritoneal protein ve aminoasit kayıpları

Lipit ve karbonhidrat metabolizmasındaki
anormallikler
Diğer kronik hastalıklar, çeşitli vasküler hastalıklar
Aminoasit yetersizliği veya dengesizliği
Anemi
Fiziksel inaktivite
Diyalizatla glukoz emilimi
Sitokinlerin artması, inflamasyon, enfeksiyonlar
Böbrek işlevlerinin kaybı
D vitaminin metabolizmasındaki anormallikler
Renal osteodistrofi
Azalmış kas aktivitesi
Yaş
Peritonit

Amerika Birleşik Devletleri'nde Ulusal Böbrek Vakfı'nın Böbrek Hastalığı Sonuçları Kalite Girişimi (NKF/KDOQI/National Kidney Foundation Kidney Disease Outcomes Quality Initiative) rehberlerine göre, SDBY olan hastaların nütrisyonel değerlendirilmesinde klinik değerlendirme ve biyokimyasal testlerin beraber yorumlanmasının en doğru sonuca ulaştıracağı ve düzenli diyaliz tedavisi gören hastalarda beslenme durumunun değerlendirilmesinin tek bir ölçümden ziyade geçerliliği kanıtlanmış ve birbirini tamamlayan ölçümlerin kombinasyonu sonucu yapılması gerektiği belirtilmiştir (14). SDBY olan hastalarda protein enerji malnütrisyonunun farklı şekillerde değerlendirilmesi Tablo 2'de özetlenmiştir $(12,15)$.

Tablo2. SDBY olan hastalarda beslenmenin değerlendirilmesi $(12,15)$

Beslenmenin değerlendirilmesi

1. İlaç öyküsü ve fiziksel muayene

2. Diyet hikayesi

- Görüşme

- 3 günlük besin tüketim kaydı

3. Antropometrik ölçüm

- Boy uzunluğu-vücut ağırlığı

- Beden kütle indeksi (BKİ, kg/m²)

- Relatif vücut ağırlığı (\%)

- Triseps deri kıvrım kalınlığı (mm) (TDKK)

- Üst orta kol çevresi (cm) (ÜOKÇ)

4. Biyokimyasal laboratuvar testleri

- Kan üre azotu, kreatinin

- Albümin, total protein, prealbümin, ferritin

- Total kolesterol, transferrin

- Prediyaliz serum potasyum

- İnsülin benzeri büyüme faktörü (IGF-1)

- C-Reaktif Protein (CRP)

5. Üre kinetik model

6. İmmün sistem işlevi

7. Vücut bileşimi

- Total vücut suyu, Bioelektrik empedans analizi (BIA)

- Magnetik rezonans görüntüleme (MRI)

- Dual X Ray Absorptiometre (DXA)

8. Subjektif Global Değerlendirme (SGD), MUST, NRS 2002 gibi subjektif yöntemler

9.Malnütrisyon İnflamasyon Skoru (MIS)

\section{Biyokimyasal Parametreler}

\section{Serum albümin}

Nütrisyonel ölçümlerden serum albümin düzeyi viseral protein depolarının yeterliliğini ve hastanın genel klinik durumunu yansıtır. Yapılan çalışmanın 
sonucunda düşük serum albümin düzeyinin hemodiyaliz hastalarında malnütrisyonun iyi bir prognostik göstergesi olduğu vurgulanmıştır (16). Albüminin yarılanma ömrü yaklaşık 20 gündür. Bu durum serum albümin düzeyini geç bir beslenme indeksi haline getirmektedir ki intra ve ekstravasküler sisteme geçişinin ve sentez katabolizma hızının değişken olması nedeniyle malnütrisyonun geç döneminde yol gösteren bir parametre olduğu kabul edilmiştir (5). European Best Practice Guidelines (EBPG)'a göre böbrek hastalarında serum albümin düzeyinin $4 \mathrm{~g} /$ dL'nin üzerinde olması gereklidir (Kanıt düzeyi III) (17).

\section{Prealbümin (Transtiretin)}

PEM'i göstermek için kullanılan biyokimyasal parametrelerden biri de serum prealbümin düzeyidir. Yarı ömrü 2 ile 3 gün arasında değişmektedir. Günlük protein alımı azaldığında serum prealbümin düzeyleri düşmekte ama uygun beslenme desteğiyle ile 2-3 gün içinde normale dönmektedir. Bu nedenle kısa dönem beslenme değişikliklerinin değerlendirilmesi için kullanımı yararlı olmaktadır (18). Böbrek hastalarında serum prealbümin düzeyinin $30 \mathrm{mg} / \mathrm{dL}$ 'nin üzerinde olması gereklidir (Kanıt düzeyi III) (17).

\section{Kan üre nitrojeni (BUN)}

Nütrisyonel durumu değerlendirmek için kullanılabilecek parametrelerden biriside kan üre azotudur. Protein alımı ve nütrisyon göstergesi olarak kabul edilmektedir. BUN düzeyini etkileyen başlıca etmenler diyetle alınan protein miktarı, rezidüel glomerüler filtrasyon değeri ve diyaliz tedavisinin etkinliğidir. Hastalara fazla diyaliz uygulanmadığı sürece, diyaliz öncesi BUN değerinin $60 \mathrm{mg} / \mathrm{dL}$ 'den düşük olması PEM’nun bir göstergesi olabilir (9).

\section{Plazma total kolesterol}

Renal hastalarda kolesterol düzeyinin düşük olması, yetersiz protein ve enerji alımını işaret etmektedir. Ayrıca serum kolesterol düzeyinin düşüklüğünün yüksek mortaliteyi predikte ettiği belirtilmektedir (19). NKF/KDOQI rehberlerine göre, serum total kolesterol düzeyi $<150 \mathrm{mg} / \mathrm{dL}$ ise böbrek hastalarında malnütrisyon göstergesi olarak kabul edilmektedir (14).

\section{Antropometrik Ölçümler}

Uygulanabilirliği basit olan antropometrik ölçümlerin malnütrisyonu belirlemede tek başına yetersiz oldukları gösterilmiştir. Antropometrik ölçümlerin ucuz ve kolay uygulanabilir olmasına rağmen bazı dezavantajları vardır. Antropometrik ölçümlerin sonuçlarının değişmesi uzun zaman aldığından, hastalara kısa dönemli yapılan beslenme girişimlerinin etkilerini göstermekte yetersizdir. Antropometrik ölçümlerin standartları belirlenirken fiziksel aktivite, yaş, hidrasyon, ödem ve ascit durumu gibi etmenler de dikkate alınmadığı için renal yetmezliği olan hastalarda tek başına değerlendirmek hatalı olabilir $(5,20)$.

\section{Vücut Bileşimi Analizi}

SDBY'de biyoelektrik impedans sonuçları değişken olarak bulunmuştur. Bunun nedeni akut olarak değişen vücut su miktarı ve periton diyaliz hastalarında periton diyaliz mayi miktarının ölçümlerin doğruluğunu etkilemesidir. Dual X Ray Absorptiometre (DXA), pahalı olduğu ve deneyimli çalışmacılar istediği için, halen çok az merkezde uygulanmaktadır (14).

\section{Subjektif Yöntemler}

\section{Subjektif global değerlendirme (SGD)}

Subjektif global değerlendirme, pratik, ucuz, farklı disiplinler tarafından kolayca kullanılabilecek, hızlı uygulanabilecek bir yöntemdir. Sonuçlarının duyarlılığı nedeniyle diyaliz hastalarının izleminde tercih edilmesi gerektiği vurgulanmaktadır (20). Ciddi malnütrisyonu ayırt etmek için SGD kullanılmalıdır (Kanit düzeyi III) (17). 


\section{Malnütrisyon inflamasyon skorlama (MIS)}

Beslenme durumunun değerlendirmesinde kullanılan yöntemlerden bir diğeridir. Bu skorlama, SGD’ye göre daha kapsamlı sorgulama içerir. Serum albümin, total demir bağlama kapasitesi, BKİ ile birlikte değerlendirilir Diyaliz hastalarında MIS’ın mortalite ve morbiditeyle ilişkisi olduğu belirtilmektedir. MIS skoru arttıkça malnütrisyon ve inflamasyon artmaktadır ve yüksek MIS skoru nütrisyonun bozulduğunun göstergesidir (21).

\section{Besin Tüketimi}

Beslenme öyküsü ve besin tüketim kayıtları da hastaların beslenmeleri konusunda bilgi verir ve malnütrisyon gelişimi açısından riskte olup olmadığının belirlenmesine yardımcı olmaktadır. Renal diyetisyenler, mutlaka besin kayıtları için besin ögesi alımı miktarını saptama konusunda iyi eğitilmelidir. Pratik uygulamalarda uzun süreli besin tüketimi alınması hastaların sıkılıp yanlış sonuç verip, yanlış bilgiler edinilmesine neden olabileceğinden hastaların günlük besin tüketimlerini almak daha uygundur (22).

Sonuç olarak, son dönem böbrek yetmezliği olan hastalarda malnütrisyon kriterleri, serum albümini $<4 \mathrm{~g} / \mathrm{dL}$, kolesterol $<150 \mathrm{mg} / \mathrm{dL}$, transferrin <200 $\mathrm{mg} / \mathrm{dL}$, vücut ağırlığı ideal ağırlığın <\%85'inden az, antropometrik ölçümlerde belirgin azalma $(<\% 15)$, düşük serum kreatinin ( $<8 \mathrm{mg} / \mathrm{dL})$ ve BUN ( $<60 \mathrm{mg} / \mathrm{dL})$, insülin benzeri büyüme faktörü (IGF-1) $<300 \mathrm{mcg} / \mathrm{L}$, tahmini kuru ağırlığın sürekli azalması, prediyaliz döneminde düşük serum potasyumu, prealbümin $<30$ $\mathrm{mg} / \mathrm{dL}<35 \mathrm{kkal} / \mathrm{kg} / \mathrm{gün}$ altında enerji alımı, BKİ <20 kg/m², SGD: B, C'dir (23) olmalıdır. Ayrıca, hastanın nütrisyonel durumu diyaliz başlangıcında ve her 3-6 ayda bir değerlendirilmelidir. SDBY olan hastalarda beslenme ile ilgili parametrelerin ölçüm sıklığı Tablo 3 'de gösterilmiştir $(5,24,25)$.
Tablo 3. SDBY olan hastalarda beslenme ilgili parametrelerin ölçüm sıklığı $(5,24,25)$

\begin{tabular}{ll}
\hline Parametre & Sıklık \\
\hline Biyokimyasal bulgular & Aylık \\
Vücut ağırlığı ve BKİ & Aylık \\
Standart (NHANES II) vücut ağırlığının yüzdesi & 4 ayda bir \\
Antropometrik ölçümler & 3 ayda bir \\
Diyaliz yeterliliği (Kt/V, URR) & 3 ayda bir \\
SGD & 6 ayda bir \\
Diyeti konusunda bilgi verilmesi & Aylık \\
nPNG (nPNG>1.0 g/kg/gün) & 6 ayda bir \\
\hline nPNG: Normalleştirilmiş Protein nitrojen görünümü, NHANES: Ulusal Sağllk \\
ve Nütrisyon İnceleme Araştırması, URR:Üre azalma oranı, KT/V: Diyaliz \\
$\begin{array}{l}\text { yeterliliğini saptamada kullanılan ölçüm, BKİ:Beden kütle indeksi, } \\
\text { SGD: Subjektif global değerlendirme }\end{array}$
\end{tabular}

\section{SONUÇ VE ÖNERİLER}

Sonuç olarak, böbrek hastalıklarında beslenme durumunun değerlendirilmesi tek bir ölçümden ziyade geçerliliği kanıtlanmış ve birbirini tamamlayan ölçümlerin kombinasyonu sonucu yapılmalıdır.

Çıkar çatışması - Conflict of interest: Yazarlar çıkar çatışması olmadığını beyan ederler. - The authors declare that they have no conflict of interest.

\section{KAYNAKLAR}

1. U.S. Renal Data System. USRDS 2013 Annual data report: Atlas of chronic kidney disesase and end-stage renal disease in the United States. Incidence, prevalence, patient characteristics. Available at: http://www.usrds. org/adr.aspx Accessed May 15, 2015.

2. Süleymanlar G, Seyami N, Altıparmak M. Türkiye'de Nefroloji- Diyaliz ve Transplantasyon. Türk Nefroloji Derneği kayıt sistemi 2013 Yllı rapor özeti. Türk Nefroloji Derneği Yayınları, İstanbul, 2013.

3. Aydın Z, Sevim Y, Döner B, Gürsu M, Karadağ S, Uzun $S$ ve ark. Hemodiyaliz hastalarında antropometrik ölçümler. Turk Neph Dial Transpl 2015;24(1):61-67.

4. Wilkens Kg, Juneja V, Shanaman E. Medical Nutrition Therapy for Renal Disorders. In: Mahan LK, EscottStump S, Raymond J, editors. Krause's Food and Nutrition Care Process.13th ed. USA: Saunders Elsevier; 2012. p.799-831.

5. Sezer S, AratZ, Özdemir FN. Kronikböbrek yetmezliğinde malnutrisyon. Turk Neph Dial Transpl 2000;3:125-9.

6. Caimi G, Carollo C, Presti R. Pathophysiological and clinical aspects of malnutrition in chronic renal failure. Nutr Res Rev 2001;21:343-79. 
7. Chertow GM, Ackert K, Lew NL, Lazarus JM, Lowrie EG. Prealbumin is as important as albumin in the nutritional assesment of hemodialysis patients. Kıdney Int 2000;58(6):2512-7.

8. Qureshi AR, Alvestrand A, Divino-Filho JC. Inflammation, malnutrition, and cardiac disease as predictors of mortalitity in hemodialysis patients. JASN 2001;13:2836.

9. ÜnalHÜ,KorkmazM,SelçukH.Kronikböbrekhastalarında malnutrisyon patogenezi ve değerlendirilmesi. Güncel Gastroenteroloji 2010;14(2):103-11.

10. Lindholm $B$, Heimbürger $O$. What are the causes of protein energy malnutrition in chronic renal insufficiency? Am J Kidney Dis 2002;39(2):422-5.

11. Mehrotra R, Kopple JD. Nutritional management of maintenance dialysis patients: why aren't we doing better? Annu Rev Nutr 2001;21:343-79.

12. Pupim LB, İkizler A. Assessment and monitoring of uremic malnutrition. J Ren Nutr 2004;14:6-9.

13. Locatelli F, Fouque D, Heimburger O, Drüeke TB, CanataAndia JB, Hörl W, Ritz W. Nutritional status in dialysis patients: A European Concensus. Neph Dial Transpl 2002;17:563-572.

14. Kopple JD. Rationale for an International Federation of Kidney Foundations. Am J Kidney Dis 2000;36:1059-70.

15. Lindsay R. The nutritional status of chronic renal failure patients following the initiation of hemodialysis treatment. Am J Kidney Dis 2002;40(1):205-7.

16. Blumenkrantz M. Beslenme. In: Daugirdas J, Blake P, editors. Diyaliz El Kitabı. 3. Baskı. İstanbul: Güneş Kitabevi; 2003. s. 374-99.
17. Fouque D, Vennegoor M, Ter Wee P, Wanner C, Baser A. EBPG guideline on nutrition. Nephrol Dial Transplant 2007;22(Suppl 2):45-87.

18. Beck FK, Rosenthal TC. Prealbumin: a marker for nutritional evaluation. Am Fam Physican 2002;65,15758.

19. Levy J, Morgan J, Browb E. (İ. Uslan, Çev.). Oxford Diyaliz El Kitabı. İstanbul: Nobel Tip Kitabevleri; 2004.

20. Afşar B, Elsürer R. Son dönem böbrek yetmezliği hastalarının nütrisyonel durumlarının değerlendirilmesinde kullanılan yöntemler. Türkiye Klinikleri J Nephrol 2008;3(2):71-7.

21. Oğuz Gök E, Erek M, Dede F. Programlı hemodiyaliz hastalarında beslenme ve malnutrisyon. İç Hastalıkları Dergisi 2013;20:121-7.

22. Kalantar-Zadeh K, İkizler TA, Block G, Morrel M, Kopple JD. Malnutrition-inflammation complex syndrome in dialysis patients: causes and consequences. Am J Kidney Dis 2003;42(5):864-81.

23. Oğuzhan $\mathrm{N}$, Utaş $\mathrm{C}$. Kronik böbrek yetmezliğinde malnutrisyon. Türkiye Klinikleri J Nephrol-Special Topics 2009;2(2):26-33.

24. Levey A, Coresh J. National Kidney Foundation-K/DOQI Clinical practice guidelines for chronic kidney disease. Evalution classification and stratification. Am J Kidney Dis 2002;39(2) (suppl 1):1-266.

25. Ash S, Campbell C, MacLaughlin H. Evidence based practice guidelines for the nutritional management of chronic kidney disease. Nutrition Dietetics 2006;63(Suppl 2):35-45. 